\title{
Radioactive Air Emissions Notice of Construction 241-ER-311 Catch Tank
}

\section{United States}




\section{Radioactive Air Emissions Notice of Construction 241-ER-311 Catch Tank}

Date Published

November 1999

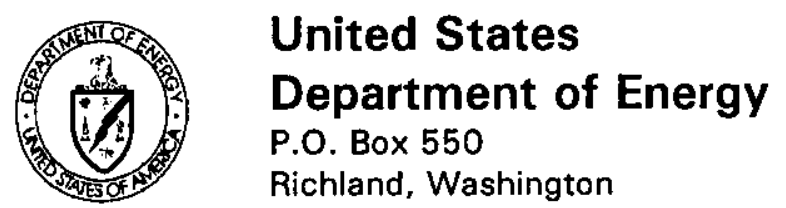




\section{RELEASE AUTHORIZATION}

Document

Number:

\section{Document}

Title:
DOE/RL-99-81, REV. 0

Radioactive Air Emissions Notice of Construction 241-ER-311 Catch Tank

\section{This document, reviewed in accordance with \\ DOE Order 241.1, "Scientific and Technical Information Management," and DOE G 241.1-1, \\ "Guide to the Management of Scientific and \\ Technical Information," does not contain \\ classified or sensitive unclassified information and is:}

\section{APPROVED FOR PUBLIC RELEASE}

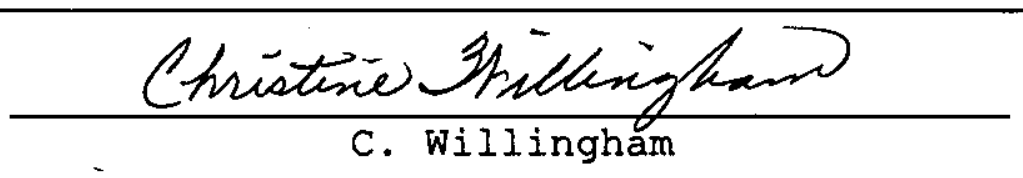

$11 / 11 / 99$

C. Willingham

Date

Lockheed Martin Services, Inc.

Document Control / Information Clearance

Reviewed for Applied Technology, Business Sensitive, Classified, Copyrighted, Export Controlled, Patent, Personal/Private, Proprietary, Protected CRADA, Trademark, Unclassified Controlied Nuclear Information.

TRADEMARK DISCLAIMER. Reference herein to any specific commercial product, process, or service by trade name, trademark, manufacturer, or otherwise, does not necessarily constitute or imply its endorsement, recommendation, or favoring by the United States Government or any agency thereof or its contractors or subcontractors. The views and opinions of authors expressed herein do not necessarily stale or reflect those of the United States Government or any agency thereof. This report has been reproduced from the best avallable copy.

Printed in the United States of Americs.

Available to the U.S. Department of Energy and its contractors from the U.S. Department of Energy Otrice of Scientific and Technical Information, P.O. Box 62, Oak Ridge, TN 37831; Telephone: 423/576-8401.

Available to the public from the U.S. Department of Commerce National Technical Information Service, 5285 Port Royal Road, Springfield, VA 22161; Telephone: 703/487-4650. 


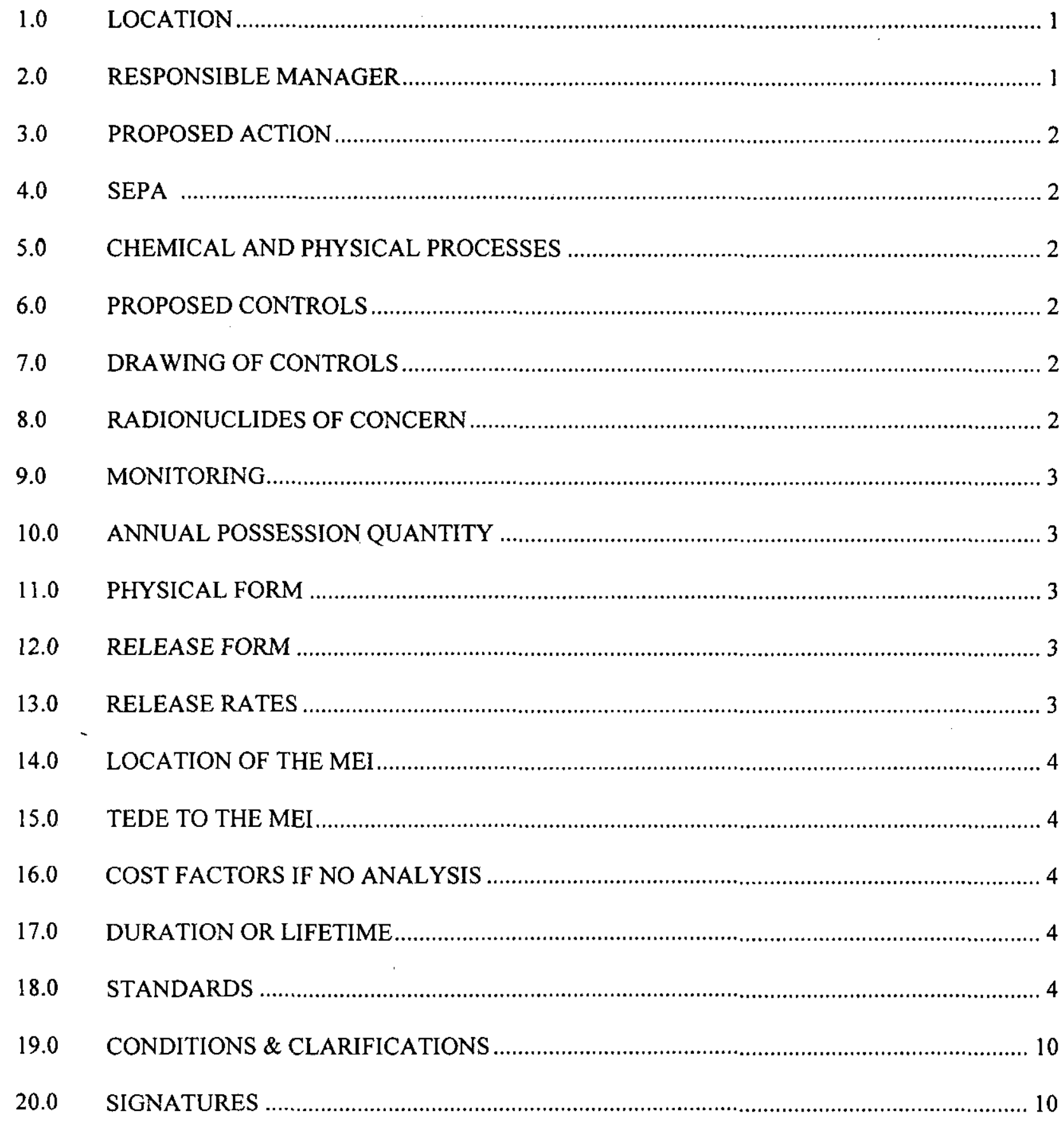




\section{FIGURES}

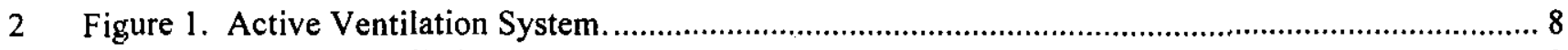

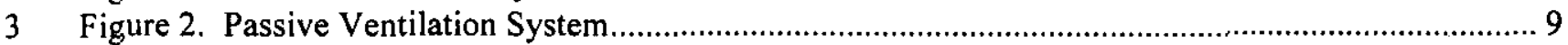




\title{
RADIOACTIVE AIR EMISSIONS NOTICE OF CONSTRUCTION 241-ER-311 CATCH TANK
}

\author{
(Approval Requested)
}

The following description, attachments and references are provided to the Washington State Department of Health (WDOH), Division of Radiation Protection, Air Emissions \& Defense Waste Section as a notice of construction (NOC) in accordance with the Washington Administrative Code (WAC) 246-247, Radiation Protection - Air Emissions. The WAC 246-247-060, "Applications, registration and licensing," states "This section describes the information requirements for approval to construct, modify, and operate an emission unit. Any NOC requires the submittal of the information listed in Appendix A." Appendix A (WAC 246$247-110$ ) lists the requirements that must be addressed.

Additionally, the following description, attachments and references are provided to the U.S. Environmental Protection Agency (EPA) as an NOC, in accordance with Title 40, Code of Federal Regulations (CFR), Part 61, "National Emission Standards for Hazardous Air Pollutants." The information required for submittal to the EPA is specified in 40 CFR 61.07. The potential emissions from this activity are estimated to provide less than 0.1 millirem/year total effective dose equivalent (TEDE) to the hypothetical offsite maximally exposed individual (MEI), and commencement is needed within a short time frame. Therefore, this application is also intended to provide notification of the anticipated date of initial startup in accordance with the requirement listed in 40 CFR 61.09(a)(1), and it is requested that approval of this application will also constitute EPA acceptance of this 40 CFR 61.09 (a)(1) notification. Written notification of the actual date of initial startup, in accordance with the requirement listed in 40 CFR 61.09(a)(2) will be provided later.

Emissions associated with the proposed activity will provide an estimated unabated and abated TEDE to the MEI of approximately $5.92 \mathrm{E}-02$ and $2.96 \mathrm{E}-05 \mathrm{millirem} / \mathrm{year}$, respectively.

\subsection{LOCATION}

The 241-ER-311 Catch Tank is located in the 200 East Area on the Hanford Site.

$$
\begin{array}{lll}
\text { Coordinates: } & \text { Latitude: } & 46^{\circ} 33^{\prime} 19^{\prime \prime} \mathrm{N} \\
& \text { Longitude: } & 1199^{\circ} 32^{\prime} 42^{\prime \prime} \mathrm{W}
\end{array}
$$

\subsection{RESPONSIBLE MANAGER}

R. T. French, Manager

U.S. Department of Energy, Office of River Protection

P.O. Box 550

Richland, Washington, 99352. 


\subsection{PROPOSED ACTION}

This NOC proposes the installation and use of a new emissions unit for the 241-ER-311 Catch Tank.

\subsection{SEPA}

The proposed action is categorically exempt from the requirements of the State Environmental Policy Act under WAC 197-11-845.

\subsection{CHEMICAL AND PHYSICAL PROCESSES}

The 241-ER-311 catch tank receives drainage from the 241-ER-151 and 241-ER-152 diversion boxes. The catch tank consists of a horizontal cylindrical vessel made of stainless steel $9 \mathrm{ft}$ in diameter and 36 feet long, and a pump pit above the tank.

The tank has a maximum capacity of 17,684 gallons. Rainwater intrusion and occasional high pressure flush of 241-ER-152 is the only source of water to the 241-ER-311 catch tank. The maximum expected volume of liquid draining to the 241-ER-311 catch tank is 212,208 gallons based on the tank filling twelve times (12) per year. If necessary, chemicals, primarily sodium hydroxide and sodium nitrite, can be injected directly into the catch tank to adjust the chemistry of the tank contents to meet the requirements for pumping liquid to the Double-Shell Tank Farms.

Due to an unexpected increase of hydrogen gas in the headspace of the tank, the tank will be filled with argon to displace the hydrogen gas in the headspace. After displacing the headspace, a passive or powered ventilation unit will be installed on the tank. (See Figures 1 and 2).

\subsection{PROPOSED CONTROLS}

If a powered ventilation unit is installed, two stages of testable HEPA filtration will be installed, although credit is being taken for only one HEPA filter. The HEPA filters have an in-place tested minimum efficiency of $99.95 \%$ for particles with a median diameter of 0.3 microns. The annual average volumetric flow rate is 0.57 cubic meters per second ( 34 cubic meters per minute).

If a passive vent is installed, Figure 2, the passive vent will have one testable stage of HEPA type filtration with a minimum efficiency of $99.95 \%$ for particles with a median diameter of 0.3 microns.

\subsection{DRAWING OF CONTROLS}

See Figures 1 and 2.

\subsection{RADIONUCLIDES OF CONCERN}

Radionuclides that may be seen are $3 \mathrm{H}, 14 \mathrm{C}, 59 \mathrm{Ni}, 60 \mathrm{Co}, 63 \mathrm{Ni}, 79 \mathrm{Se}, 90 \mathrm{Sr}, 90 \mathrm{Y}, 93 \mathrm{Zr}, 93 \mathrm{mNb}, 99 \mathrm{Tc}$, 106Ru, 113mCd, 125Sb, 126Sn, 129I, 134Cs, 137Cs, 137mBa, 151 Sm, 152Eu, 154Eu, 155Eu, 226Ra, 227Ac, 228Ra, 229Th, 231 Pa, 232Th, 232U, 233U, 234U, 235U, 236U, 237Np, 238Pu, 238U, 239Pu, $240 \mathrm{Pu}, 241 \mathrm{Am}, 241 \mathrm{Pu}, 242 \mathrm{Cm}, 242 \mathrm{Pu}, 243 \mathrm{Am}, 243 \mathrm{Cm}, 244 \mathrm{Cm}$. As shown in the Attachment, the radionuclides of concern are $\mathrm{Sr}-90$ and $\mathrm{Cs}-134$. 
1

\subsection{MONITORING}

If the powered ventilation system is used, the exhaust stack will contain an air velocity probe (for measurement of stack velocity) and an air sampling probe (see discussion in Section 18). The monitoring system, identified as the generic effluent monitoring system (GEMS), has been subject to extensive testing and shown to meet all applicable regulatory criteria for air sampling at nuclear facilities. The performance criteria addressed both the suitability of the air sampling probe location and the transport of the sample to the collection devices.

The system includes a stack section containing the sample probe and another stack section containing the airflow, temperature, and humidity sensors. The GEMS design features a probe with a single shrouded sampling nozzle, a short sample delivery line, and a sample collection system. The collection system includes a filter holder to collect the record sample and the continuous air monitor is being by-passed due to it not meeting the Class I, Division I, Group B National Electrical Code criteria. As a result, the continuous air monitor will not be operating. The record sampler will operate continuously during exhauster operation.

For the passive ventilation system, periodic confirmatory measurements of low emissions will be verified by smearing the outlet of the HEPA filter housing.

\subsection{ANNUAL POSSESSION QUANTITY}

The annual possession quantity is based on prior tank sampling data contained in a Westinghouse Internal Memo, 96-074, from T. M. Blaak to G.N. Hanson, dated July 12, 1996. The concentrations were multiplied by the volume of the tank, 17,684 gallons, and then twelve (12) assuming that the tank fills up an average of once per month. The assumptions are conservative since the tank primarily receives stormwater intrusions and the tank was last pumped on August 7, 1996, to a level of approximately 1797 gallons. The tank level on November 5, 1999, is approximately 7,400 gallons; therefore, approximately 5,600 gallons of liquid has accumulated over the past 3 years. The Attachment contains the annual possession quantity associated with each radionuclide.

\subsection{PHYSICAL FORM}

All radionuclides listed in Section 8 are present as particulate solids at ambient conditions except for tritium (H-3) and carbon-14 which are present as liquids or aerosols.

\subsection{RELEASE FORM}

All radionuclides listed in Section 8 will be released as particulate solids except for tritium and carbon14 , which will be released as a gas.

\subsection{RELEASE RATES}

The unabated release rate for the new emission unit is $8.06 \mathrm{E}-01$ curies/year, and the abated release rate is 4.03E-04 curies/year. The release rate is based on applying the 40 CFR 61 Appendix D release fraction of $1.0 \mathrm{E}-03$ for particulates and solids to the annual possession quantity in Section 10. A detailed breakdown of the release rates for the radionuclides detected in previous sampling have been provided in the Attachment. Because data does not show evidence of tritium or Carbon-14 in the tank, they have not been considered in the release rate discussion. 


\subsection{LOCATION OF THE MEI}

The conservative location of the maximally exposed individual is 20,200 meters east southeast of the 200 East Area.

\subsection{TEDE TO THE MEI}

The potential unabated offsite dose is calculated as the product of the unabated emissions and the applicable unit dose factor contained in Calculating Potential to Emit Releases and Doses for FEMPS and NOCs (HNF-3602). The unabated and abated TEDE to the MEI for activities described in this NOC are 5.92E-02 and 2.96E-05 millirem per year, respectively. The Attachment provides a detailed summary of TEDE to the MEI.

\subsection{COST FACTORS IF NO ANALYSIS}

It is proposed that the above described HEPA filtration be approved as best available radionuclide control technology (BARCT) for the passive or active ventilation system. The WDOH has provided guidance that HEPA filtration is considered BARCT for particulate emissions. Because only particulate radionuclides are expected to be seen, HEPA filtration or HEPA type filtration would meet the requirements of BARCT. As such, cost factors for construction, operation, and maintenance of the control technology components and system have not been provided.

\subsection{DURATION OR LIFETIME}

This activity is expected to commence on November 4,1999 , and continue for up to 20 years.

\subsection{STANDARDS}

The potential TEDE received by the MEI, resulting from the proposed operations at the emission unit is less than 0.1 millirem per year. This section discusses compliance with major sections of the standards and provides justification to support adequacy of the design for sections of the standard, which are not met. The standards are discussed separately for using the powered ventilation unit or the passive ventilation unit.

For the powered ventilation system, the emissions control equipment will adhere to the compliance standards as noted below.

American Society for Engineers (ASME)/American National Standards Institute (ANSI) AG-1: This equipment specific code consists of five primary sections, which are applicable to this unit. The applicable sections are fans (Section BA), ductwork (Section SA), HEPA filters (Section FC), dampers (Section DA) and Quality Assurance (QA) (Section AA).

The fan section of AG-1 (Section BA) covers the construction and testing requirements for fans. This fan meets the applicable criteria identified in AG-1, except as identified below. It was constructed to the Air Movement and Control Association (AMCA) 99-401, Spark Resistant Construction, criteria, and was tested to the applicable sections of AMCA 210. However, it can not be shown the shaft leakage criteria is met (Section BA 4142.2). This is acceptable because a "stuffing box" is installed around the shaft to minimize the leakage, and the leakage point is located after the HEPA filters.

The next applicable requirement is the ductwork section of AG-1 (Section SA). As was the case for the fan, this section identifies several requirements for ductwork. This includes acceptable material, 
1 fabrication, and testing criteria. The ductwork used will be a combination of both metal and flexible polymer. In both cases it meets the applicable criteria but will not be pressure tested per the applicable criteria identified in AG-1 and N510 prior to operation. The ductwork will be visually inspected during operation and is under negative pressure, thus eliminating the possibility for releasing contamination.

The HEPA filter section of AG-1 (Section FC) is also applicable in this instance. The criteria identified in AG-1 were previously located in military specification 51068 and ASME 509. The filters, which are installed in the exhauster, will meet the applicable sections of AG-1, except for two areas dealing with filter qualification testing. Justification for this exception was discussed with and approved by WDOH at the December 1998 Routine Technical Assistance Meeting.

The dampers installed on the portable exhauster meet the applicable AG-1 criteria. This includes design, construction and testing. The manufacturer performed a leak test on the valves, and a pressure decay test was completed on the exhaust train system. For the pressure decay test, the valves were used for isolation. The test was successful.

The quality assurance section of AG-1 relies on ASME NQA-1. The general QA criteria are located in Section AA. Specific component/system criteria are located in each section throughout AG-1. The portable exhauster was built here on site and meets the site's QA program. This includes procurement of the safety material/components, along with appropriate pedigree from an evaluated supplier, tracking and maintaining the material/components after it arrived on site, inspection of the material/components, and witnessing the testing. Based on the above, the AG-1 criteria is met.

AG-1 contains several other sections, however they do not apply to this system. Finally, several sections of AG-1 are not yet completed. This includes the filter housing section which will be discussed below in the N509 Section.

The ASME N509 standard deals with the individual components and how they relate to the overall system. The primary section of N509 that will be discussed is the filter housing section and heater section.

The filter housing for this exhauster is compliant with the applicable sections of the N509 criteria. This includes design of housing, mounting frames, materials, and testing.

The heater used in this exhauster does not meet the N509 criteria. The reason for the heater is to assure the relative humidity of the air stream is below $70 \%$, reducing the opportunity for condensation in the filter housing. N509 states the heater shall be electric. When that section was written an electric heater was required because the only other alternative was steam heating. Steam heaters were not acceptable because if the heating coil failed, the steam, which was at such high pressure, could cause severe damage to the HEPA filters.

The newer style heater used in this exhauster is a glycol heater. The glycol medium is heated via a "hot water" heater arrangement and circulated to the heating coil via pump. The main reason an electric heater was not used is due to the flammable gas concern. This exhauster will potentially be ventilating a flammable gas air stream. If an electric heater were used, it would need to be a specific type to support the design requirements for flammable gas, and may still have the potential for fire or explosion.

The glycol heater provides the necessary heating and equipment is in place to prevent the damage of the HEPA filters if the coil were to fail. This includes level detection in the glycol reservoir, which will detect the loss of glycol. In addition, differential pressure across the first HEPA filter is monitored. If 
1 the coil were to break, the differential pressure across the first HEPA would increase and the system 2 would be shutdown.

This ASME N510 standard pertains to the testing of nuclear air cleaning systems. The first requirement identified in N510 is to perform a pressure decay test. This is to assure there are no infiltration or outward leak paths from the system. This test was completed on the portable exhauster and was successful.

This system meets the leak test criteria identified per N510. Test sections are located in the exhaust train to allow for proper independent testing of both HEPA filters.

For the passive ventilation system, the emissions control equipment will adhere to the compliance standards as noted below.

American Society of Mechanical Engineers (ASME) AG-1: This equipment specific code consists of four primary sections, which are applicable to this applicable unit. The applicable sections are for ductwork (Section SA), HEPA filters (Section FC), dampers (Section DA) and Quality Assurance (QA) (Section AA).

The ductwork section of AG-1 (Section SA) is applicable for a small section of ductwork from the top of the riser to the filter housing. The criteria include acceptable material, fabrication, and testing criteria. The ductwork used is metal and meets the applicable criteria identified in ASME AG-1. The ductwork is fabricated as an assembly from the manufacturer and is tested as an assembly with the housing per the applicable criteria identified in AG-1 and N510.

The HEPA filter section of AG-1 (Section FC) is also applicable in this instance. The criteria identified in AG-1 were previously located in military specification 51068 and ASME 509. The filters meet the applicable sections of AG-1, except for two areas dealing with filter qualification testing. Justification for this exception was discussed with and approved by WDOH at the December 1998 Routine Technical Assistance Meeting.

The damper installed on the breather filter meets the applicable AG-1 criteria. This includes design, construction and testing. The manufacturer performs a generic leak test on the butterfly valves prior to shipping.

The quality assurance section of AG-1 relies on ASME NQA-1. The general QA criteria are located in Section AA. Specific component/system criteria are located in each section throughout AG-1. The assembly meets the NQA-1 criteria.

AG-1 contains several other sections, however they do not apply to this system. Finally, several sections of AG-1 are not yet completed. This includes the filter housing section which will be discussed below in the N509 Section.

The ASME N509 standard deals with the individual components and how they relate to the overall system. The only section of N509 that will be discussed is the filter housing section. The filter housing for the breather filter is compliant with the applicable sections of the N509 criteria. This includes design of housing, mounting frames, materials, and testing.

The ASME N510 standard pertains to the testing of nuclear air cleaning systems. The first requirement identified in N510 is to perform a pressure decay test. This is to assure there are no infiltration of 
outward leak paths from the system. This is a standard test for the filter housings at the housing manufacturer's facility. This system meets the leak test criteria identified per N510.

The ANSI/ASME NQA-1 standard for quality assurance is addressed by HNF-MP-599, latest revision, "Project Hanford Quality Assurance Program Description" (Chapter 2.0, Section 3.3 and Chapter 7.0, Section 3.2) and by HNF-0528-3, "National Emission Standards for Hazardous Air Pollutants (NESHAP) Quality Assurance Project Plan for Radioactive Airborne Emissions", (all of Sections 2.0, 3.0 and 5.0) as a compatible alternative to NQA-1. This system meets the criteria.

The ANSI/ASME NQA-2 standard is no longer an active National Standard and has been incorporated 11 into NQA-1. Compliance with NQA-1 was addressed above.

1340 CFR 60, Appendix A is not applicable for passive systems.

15 ANSI N13.1 (1969) is not applicable for passive ventilation systems. 
DOE/RL-99-81, Rev. 0

$11 / 99$

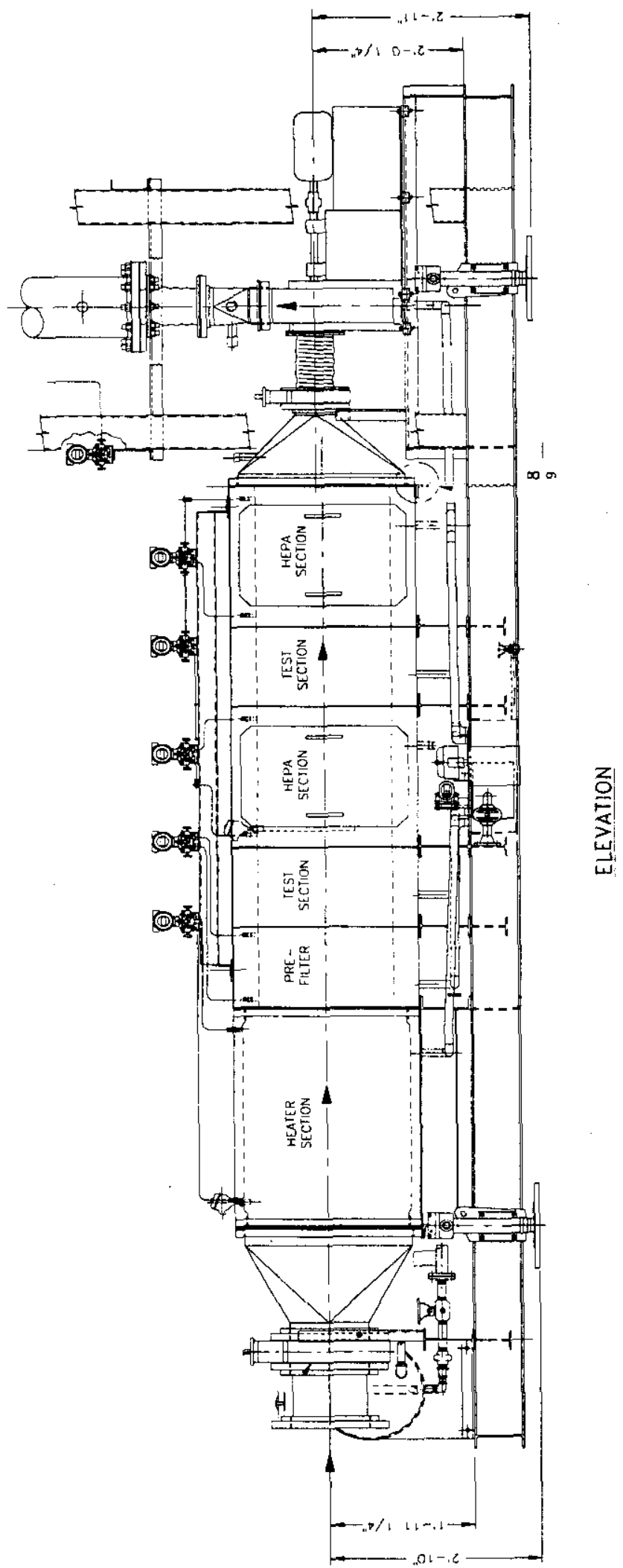

Figure 1. Active Ventilation System. 


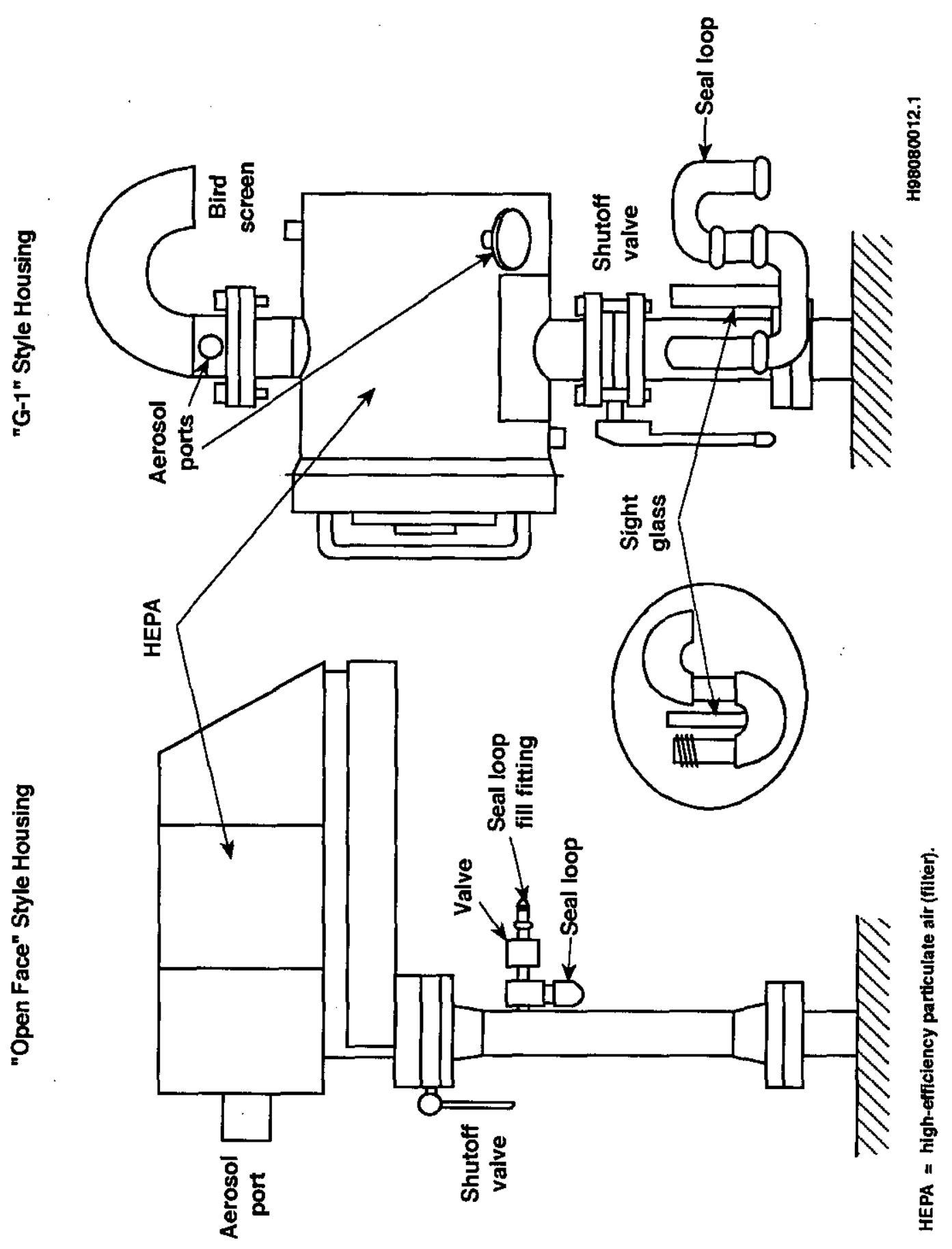

Figure 2. Passive Ventilation System 


\subsection{CONDITIONS \& CLARIFICATIONS}

\subsection{SIGNATURES}

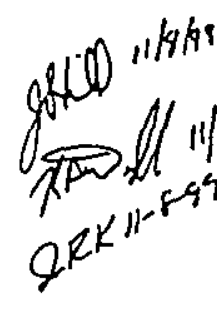

\section{his}

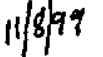

17

$4^{4}$

D. J. Carrell, Manager

LMHC Ai and Water Services

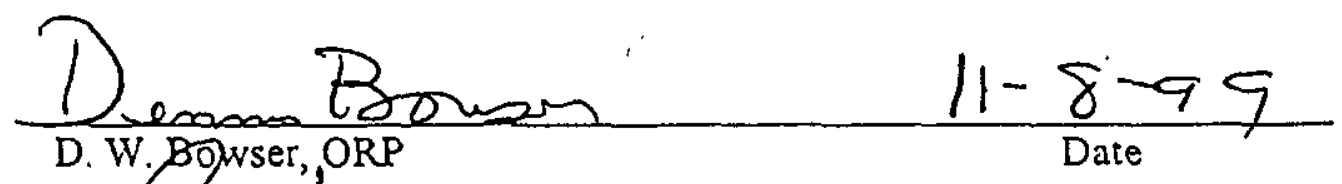

Management Sfstems Office

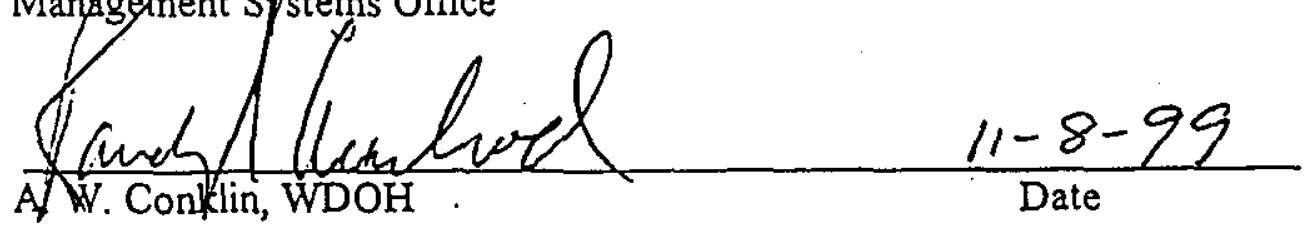

Division of Radiation Protection,

Air Emissions \& Defense Section 
This page intentionally left blank. 
DOE/RL-99-81, Rev. 0

$11 / 99$

ATTACHMENT

ESTIMATED EMISISONS ASSOCIATED WITH VENTING TANK 241-ER-311 
DOE/RL-99-81, Rev. 0

11/99

This page intentionally left blank. 


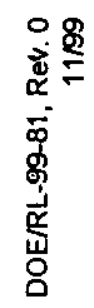

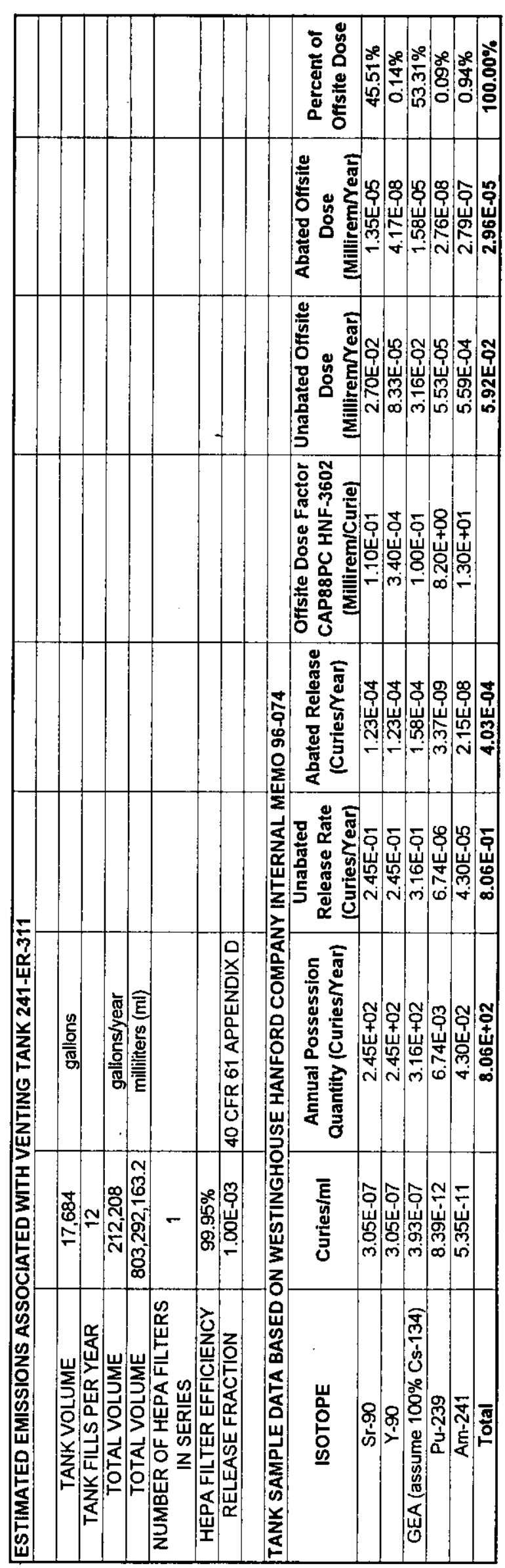

妥 
DOE/RL-99-81, Rev. 0

$11 / 99$

This page intentionally left blank. 


\section{DISTRIBUTION}

\section{J. Leitch}

United States Environmental Protection Agency

Region 10

1200 Sixth Avenue

Seattle, Washington, 98101

A. W. Conklin

Washington State Department of Health

7171 Cleanwater Lane, Building 5

Olympia, Washington 98504

R. S. Acselrod

Washington State Department of Health

PMB 385

2839 W. Kennewick, Avenue

Kennewick, Washington 99336

Dirk A. Dunning

Oregon Office of Energy

625 Marrian Street N.E., Suite 1

Salem, OR 97301-3742

J. Wilkinson

Confederated Tribes of the Umatilla Indian Nation

P. O. Box 638

Pendleton, Oregon 97801

P. Sobotta

Nez Perce Tribe

P. O. Box 365

Lapwai, Idaho 93540

R. Jim, Manager

Environmental Restoration/Waste Management Program Yakima Indian Nation P. O. Box 151

Toppenish, Washington 98948 


\section{DISTRIBUTION}

MSIN

U.S. Department of Energy, Office of River Protection

D. W. Bowser

A2-22

P. W. Kruger

H6-60

J. E. Peschong

S7-51

J. A. Poppiti

S7-54

Public Reading Room

$\mathrm{H} 2-53$

Fluor Daniel Hanford, Inc.

B. L. Curn

G1-29

Lockheed Martin Hanford Corp.

D. I. Allen

R2-50

D. J. Carrell

R1-51

D. E. Clark

R1-51

M. L. Dexter

R1-51

T. A. Dillhoff

S5-03

W. T. Dixon

R1-51

R. A. Dodd

R3-72

D. L. Dyekman

R1-51

J. S. Hill

R1-51

J. R. Kriskovich

$\mathrm{R} 1-56$

J. J. Luke

R1-51

P. C. Miller

R1-51

Pacific Northwest National Laboratory

Hanford Technical Library

P8-55

Lockheed Martin Services, Inc.

Central Files

B1-07

DPC

H6-08

EDMC (2)

H6-08 